\title{
A autobiografia e a diário como feridas na lógica da representação literánia
}

Flavia Trocoli Xavier Silva ${ }^{1}$

Resumo: Este artigo propõe pensar três momentos do trabalho de construção da escrita em Marguerite Duras, em Nuno Ramos e em Vera Lins, como inseparável de um trabalho simultâneo de destruição, reencenando a relação tensa entre obra e não-obra, em que a escrita estaria justamente no intervalo entre o já escrito e o por escrever. Os textos aqui analisados não estão integralmente ao lado da literatura, pelo contrário, eles mostram como são afetados por aquilo que, a princípio, deveria ser seu fora: a autobiografia e o diário. Tensão que não deixa de ser, para dizer com Jacques Derrida, uma paixão da literatura.

Palavras-chave: Marguerite Duras; Nuno Ramos; Vera Lins; Jacques Derrida; escrita autobiográfica.

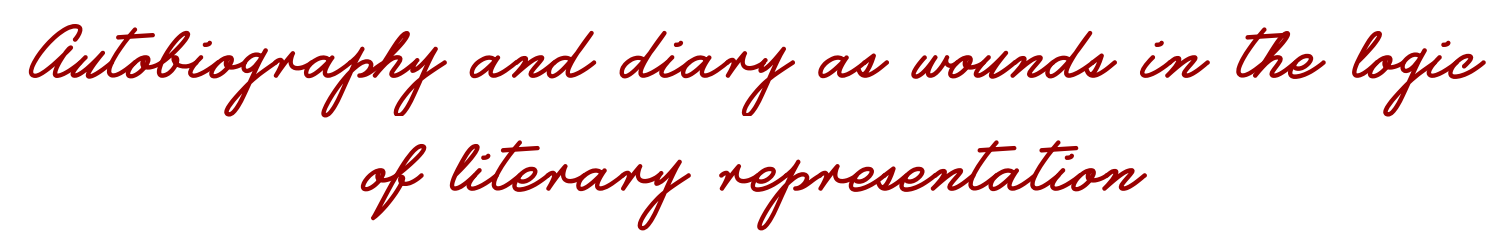

Abstract: This article proposes to examine three phases of the process of construction of the writing in Marguerite Duras, Nuno Ramos and Vera Lins. Construction will be considered as inseparable from a simultaneous process of destruction, reenacting the tense relationship between work and non-work - writing takes place precisely in the interval between what has been written and what is about to be written. The texts analysed here are not totally on the same side as literature. On the contrary, they demonstrate how they have been affected by what initially ought to be outside literature: autobiography and diary; a tension which is nonetheless, in the words of Derrida, 'a passion of literature'.

Keywords: Marguerite Duras; Nuno Ramos; Vera Lins; Jacques Derrida; autobiographical writing.

\footnotetext{
${ }^{1}$ Professora de Teoria Literária do Departamento de Ciência da Literatura da UFRJ. E-mail: $\underline{\text { flavia.trocoli@gmail.com }}$
} 
[...] a morte de minha mãe, Sultana Esther Georgette Safar Derrida, viria esculpir a escrita do fora, dar-lhe sua forma e seu ritmo a partir de uma interrupção incalculável, jamais nenhum de meus textos terá dependido em seu dentro mais essencial de um fora tão cortante. Jacques Derrida, em Circonfissão

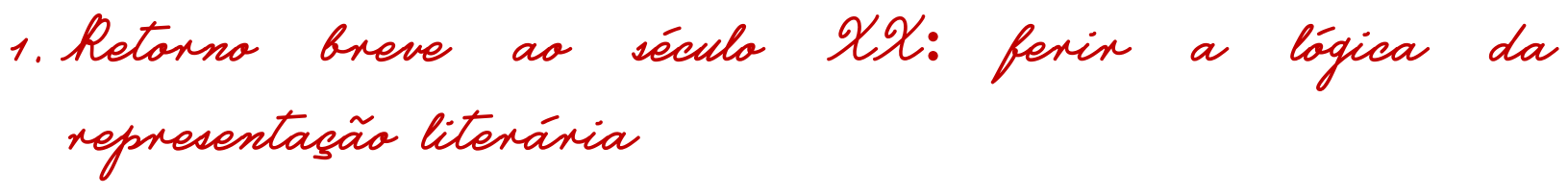

PENSAREI TRÊS MOMENTOS DA ESCRITA EM MARGUERITE DURAS, em Nuno Ramos e em Vera Lins, seguindo os rastros da leitura atenta que Paulo Fonseca de Andrade faz do conjunto da obra de Marguerite Duras. Nessa leitura, o crítico afirma que o dispositivo autobiográfico acionado é uma forma de produzir um pensamento sobre a escrita e sublinha que a passagem da experiência vivida (que, aliás, já é desde sempre linguagem) para a escrita (conversão, redução, tradução) "fazse por meio de perdas (provação, afastamento, redução)"(ANDRADE, 2010, p.122). Assim, o trabalho de construção da escrita é inseparável de um trabalho simultâneo de destruição, reencenando a relação tensa entre obra e não-obra, em que a escrita estaria justamente no intervalo entre o já escrito e o por escrever. De modo exemplar, nas últimas linhas de Em busca do tempo perdido, o narrador proustiano inscreve o livro por vir: "Se ao menos me fosse concedido um prazo para terminar a minha obra...” (PROUST, 2004, p.292). Cada qual a sua maneira, os textos analisados aqui reencenam essa tensão que não deixa de ser, para dizer com Jacques Derrida, uma paixão da literatura. No fim, retornarei à paixão em sua relação inseparável de um “fora tão cortante." É a paixão do que se passa fora da ordem da consciência, do cronológico e do significado, que fere a lógica da representação e exige a busca de uma nova forma.

Minha fantasma, de Nuno Ramos, e Desejo de escrita, de Vera Lins são obras que se dizem diário e, nisso, ressaltam seus recursos poéticos e ficcionais. Elas inauguram duas décadas do século XXI e poderiam ser lidas a partir das teorias do "boom autobiográfico" (ARFUCH, 2010, e KLINGER, 2012) às voltas com o retorno do autor e da autorreferência. No entanto, proponho analisá-las anacronicamente a partir de questões caras a um certo Modernismo, pelo menos de Marcel Proust a Marguerite Duras, ou de Sigmund Freud a Jacques Derrida.Tais questões seriam desdobramentos do descentramento tenso do eu que culminaria: 1) no apagamento dos pontos de fixação de identidade, de tempo e de espaço, e na culminância da indeterminação do ele; 2) no privilégio do corpo sensível em detrimento de uma inteligência voluntária; 3) no "fracasso da reconstituição" e na relação problemática entre fragmento e totalidade; 4) no estatuto de verdade como "verdade estética" que, neste momento, implicará pensar o autobiográfico entrelaçado ao literário. Tal "verdade estética" pode ser entendida, neste momento, como uma verdade submetida a uma forma estética que opera um deslocamento da ênfase das referências sobre as quais se apoiam o $e u$ e suas representações consistentes para o trabalho com a linguagem, matéria outra que coloca em xeque o si-mesmo.

Assim, essas obras, que inscrevem traços autobiográficos, poderiam ser analisadas como uma retomada da destituição operada pela modernidade - destituição da consciência, do significado

\footnotetext{
${ }^{2}$ A expressão é de Paulo Fonseca de Andrade na conferência intitulada "Aqui é S. Talah, até o rio - Marguerite Duras e a experiência da escrita" e proferida no Colóquio Marguerite Duras: uma poética do transbordamento, em Belém, setembro de 2014.
} 
e da totalidade. Uma vez destituído, oeu desamparado não poderá mais ser pensado a partir da lógica da propriedade, o que instaura procedimentos estéticos que se opõem justamente às questões próprias ao romance burguês do XIX. Em O burguês: entre a história e a literatura, Franco Moretti (2014) mostra o compasso entre a narração e a regularidade da existência burguesa; a retórica da prosa se assenta na regularidade, na continuidade, na precisão, na produtividade e na neutralidade. Moretti situa ainda a função dos "enchimentos", isto é, daquilo que se dá entre os momentos decisivos da trama. Esses enchimentos são a formalização da domesticação e da regularização do acaso em um tempo também assenhoreado e padronizado.

Não é o que se passa nas primeiras páginas de $O$ amante, 1984. Aquela que escreve cava buracos: a matéria de seu rosto foi destruída, a história de sua vida não existe, a fotografia do momento a ser escrito não foi registrada, foi esquecida. Pensar a fotografia inexistente e a escrita de $O$ amante implica considerar pelo menos esses dois campos: aquele que inscreve a imagem como potência de sentidos e aquele em que a imagem é cifra para o Real, barra os sentidos e força a escrever. Se a imagem absoluta, real, não foi registrada, imediatamente poderia se pensar que a escrita que vem lhe fazer suplência já estaria no campo dos significados. Engano. "Memória sem lembrança”, para dizer com Michel Foucault (2006, p.357), a escrita de $O$ amante não deixa a leitura, que é também a escrita de um rosto devastado, demorar-se em "o que isso significa", mas lança-a no buraco em que o "é isso" impõe-se. Exige-se aí uma forma que seria sem metáfora, afinal, a presença da infelicidade da mãe impede o sonho da criança, ou seja, a possibilidade de desviar-se através de figuras de linguagem. Voltarei a este ponto.

Trinta anos antes da publicação de $O$ amante, Marguerite Duras escreveu Barragem contra o Pacífico, 1950, seu terceiro romance. Narrado em terceira pessoa em um registro mais objetivo, mais contínuo e mais concatenado do que o de $O$ amante, tal romance conta a história da mãe de Suzanne ou, mais precisamente, daquilo que é chamado de "a sua loucura". Emigrada para a Indochina francesa, a mãe convence os camponeses miseráveis da região a construírem uma barragem contra o mar que "havia milênios invadia a planície". Roídas por caranguejos, durante as cheias de julho, as barragens desmoronam em uma noite. Depois disso a mãe berra, se deixa morrer e oferece a filha aos homens ricos da região para pagar as dívidas deixadas pela construção e pelo desmoronamento:

O médico disse que a origem de suas crises estava no desabamento das barragens. Talvez estivesse enganado. Tanto ressentimento só poderia ter sido acumulado lentamente, ano após ano, dia após dia. Não tinha uma causa única. Tinha mil, inclusive o desabamento das barragens, a injustiça do mundo, o espetáculo de seus filhos que se banhavam no rio... [...] a ponto de um médico poder falar agora de vê-la morrer daquilo, morrer de infelicidade. (DURAS [1950], 2003, p.20)

Se o relato de Barragem ainda se quer romanesco, o relato de $O$ amante consuma "a passagem à autobiografia confessa" (ARMEL, 1990, p.116). No entanto, tal passagem não autoriza o leitor de maneira nenhuma a criar correspondências plenas e exatas entre a suposta vida vivida e aquilo que se escreve e se atualiza em ato de escrita em $O$ amante. Nele, aquela que escreve se põe a ler a destruição do seu rosto de criança na cena de encontro com o amante chinês, e, a meu ver, o primeiro enigma colocado por essa leitura e essa escrita se configura a partir do entrelaçamento dessa cena com a história da mãe. Escrever sobre o amante implica escrever sobre a mãe. Em La 
folie de Marguerite: Marguerite Duras et sa mère, Christian Jouvenot (2008) afirma com justeza que a dupla mãe e filha estão no coração da obra durassiana. Escutemos a confissão feita ao amante chinês:

Os beijos no corpo provocam lágrimas. Como se fossem um consolo. Em casa não choro. Naquele dia, naquele quarto, as lágrimas consolam o passado e o futuro também. Digo-lhe que de minha mãe vou me separar um dia, que, mesmo minha mãe, um dia deixarei de amar. Choro. Ele encosta a cabeça em meu corpo e chora porque me vê chorar. Digo que em minha infância a infelicidade de minha mãe ocupou o lugar do sonho. O sonho era minha mãe e jamais árvores de Natal, sempre ela, só ela, fosse a mãe esfolada viva pela miséria ou a mãe descontrolada que pregava no deserto, fosse a que procurava alimento ou a que contava interminavelmente o que havia acontecido a ela Marie Legrand de Roubaix, ela fala de sua inocência, suas economias, sua esperança. (DURAS [1984], 2003, p.40)

Nota-se a clara dimensão de endereçamento - endereçamento que não há na narrativa de Barragem contra o Pacífico - pois o que é dito é dito ao amante, o primeiro confidente, quando a escritora decide quebrar o silêncio em relação às misérias familiares. Essa dimensão de apelo não se reduz à escuta de seu amante, o olhar do leitor também é convocado: "Na balsa, olhem para mim”. Se a voz e o olhar compõem essa escrita, tampouco as relações de contiguidade podem ser desprezadas na leitura de $O$ amante. Antecedendo esse trecho citado, a narradora diz que sempre fora triste e que tal tristeza é um bem-estar de "ter afinal caído na infelicidade que minha mãe anuncia há tanto tempo, quando ela uiva no deserto de sua vida” (DURAS [1984], 2003, p.39) Em A dor (1985), livro também assumidamente autobiográfico sobre o retorno de Robert Antelme do campo de concentração, aquela que escreve irá dizer que a dor foi a coisa mais importante de sua vida. Assim, se ao falar de outra Marguerite, a Aimée de Lacan, Jean Allouch pôde dizer que Marguerite ama o seu delírio, o seu, mas igualmente o de sua mãe como a si mesma. Aqui, podemos dizer que Marguerite Duras também terá amado a dor de sua mãe como a si mesma, mas não ficará na catástrofe, uma vez que os tempos da reescrita lhe permitirão conhecer o prazer que a mãe não conheceu.Eis o traço que a distingue e a separa da mãe.

Importante destacar que aquela que escreve diz que, até a escrita de $O$ amante, "Escrevi muito sobre essas pessoas da minha família, mas enquanto o fazia eles ainda estavam vivos, a mãe e os irmãos, e escrevi em torno deles, em torno dessas coisas sem chegar até elas.” (DURAS [1984], 2003, p.10) O que, então, faz de a escrita de $O$ amante um modo de chegar até elas? Feita a pergunta, a própria narradora nos indica um caminho para respondê-la quando afirma que "não se trata de conseguir alguma coisa, mas de sair de onde estamos" (DURAS, p.22) Se Barragem contra o pacífico termina com a morte da mãe e com o anúncio da partida da filha, $O$ amante termina com um telefonema do amante chinês "anos depois da guerra, depois dos casamentos, dos filhos, dos divórcios, dos livros," neste telefonema ele diz que ainda a ama. Não se pode ler no cruzamento desses dois finais a passagem da filha prostituída à mulher amada? Essa passagem não se deve ao apagamento que a reescrita provoca? À passagem dos conteúdos da lembrança para as formas da memória?

É preciso distinguir entre a narrativa regular e mais objetiva de Barrageme a escrita descontínua de $\mathrm{O}$ amante. Na narrativa, um narrador impessoal; na escrita, uma voz que joga com a sua própria dessubjetivação, com o rosto devastado que emerge e desaparece nas águas do rio 
Mekong e constitui índice de uma travessia. E não é este deslocamento - de uma história pessoal narrada com pretensão de objetividade à escrita singular de uma história que não existe - que coloca em outra chave o traço autobiográfico em sua passagem de algo privado para o público, fazendo com que o "cume do particular", segundo a expressão proustiana, possa passar sem obscenidade ao público?

Quase ao final da escrita, depois da miséria, da infelicidade, do desespero, da loucura, depois dos muitos tempos da devastação, de a mãe ter se tornado escrita, a escritora pode dizer de uma graça profunda:

Jamais tirava fotografias de lugares, de paisagens, só dos filhos, e quase sempre nos agrupava para que a fotografia ficasse mais barata. [...] Misteriosamente minha mãe mostra as fotografias dos filhos à sua família durante as férias. [...] Será que se pode perceber algo sobre essa mulher por esse modo de agir? Por meio dessa sua disposição para ir sempre até o fim de tudo, sem jamais imaginar que poderia abandonar, pôr de lado as primas, a dor, as tarefas penosas? Acho que sim. É nessa coragem especial, absurda, que encontro a graça profunda. (DURAS [1984], 2003, pp. 78-79)

Ao final, aquela que narra torna-se escritora e a mãe torna-se essa mulher. Para além de um luto pautado pela substituição, a escrita de $O$ amante pode ser pensada como a perda do rosto da menina que, ao entrar no carro fúnebre do amante chinês, perfaz o primeiro giro que a separa de uma família petrificada no desespero, uma família que, como a de Antígona, não pode fazer sepulturas. Se a fotografia desse momento e de uma primeira separação pudesse ter sido tirada, "contingência soberana," para dizer com Roland Barthes (2000), ela teria sido a "imagem absoluta", primeiro título cogitado para o livro, a imagem dessa perda, a do rosto da criança, coincidiria com a perda da Mãe absoluta, a que ocupou o lugar das árvores de Natal, do sonho. Presença absoluta confessada ao amante. Contudo, essa imagem que não existe, ato de inscrição de uma perda, atualiza-se nos dêiticos: essa mulher, aquela mulher. Sem pertença possível à ordem da prosa realista, à ordem do significado, o significante mulher, em $O$ amante, de Marguerite Duras, faz ressoar a exceção feminina, tal qual pensada por Gérard Pommier: " 'Mulher' é essa palavra, única em seu gênero na língua, cujo ponto de referência faz falta. [...] A feminilidade se resume na apresentação desse ornamento do vazio, no qual ela inexiste." (Pommier, 1991, p.33)Travessia do "eu sou a filha” para a designação indeterminada do "essa mulher". Essa travessiada penumbra,quando se passa da ilusão referencial para a materialidade da palavra que empresta corpo à experiência, provoca um curto circuito na dêixis e na representação. Logo, o que está em jogo não é a reconstituição de um retrato ou de um fato, mas a inscrição de uma dor, uma ferida, no corpo do texto. Assim será também em Nuno Ramos.

2 .
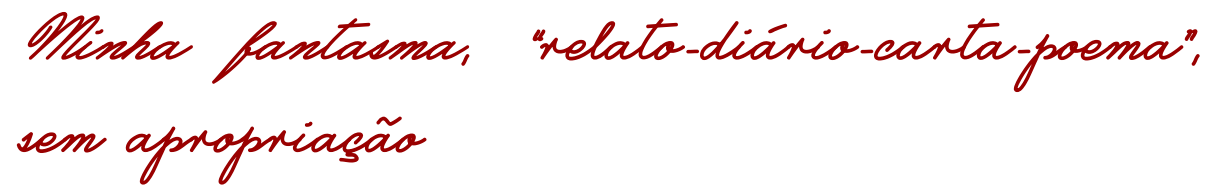

uma

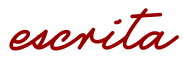

Em outro momento, pensei o narrador do diário de Nuno Ramos em contraponto com os narradores modernos de Dom Casmurro, de Machado de Assis, e de São Bernardo, de Graciliano Ramos (TROCOLI, 2010). Em Dom Casmurro e em São Bernardo, a mulher amada provoca o 
silêncio e a injunção à escrita. Cada um a seu modo, os narradores escrevem uma perda da onisciência que convém à lógica do proprietário: Bentinho através da suspeita dissimulada em certeza da traição, Paulo Honório através da confissão doequívoco da interpretação. É o não-dito em forma de lacunas e elipses que coloca a acusação e a mestria de Bentinho sob suspeita e faz de seu relato uma ferida na memória. É a morte de Madalena que lança Paulo Honório em um universo fora de seu controle (LAFETÁ, 2004). Deste modo, uma diferença pode ser assinalada entre Dom Casmurro, São Bernardo e Minha fantasma, a saber: neste último, não há um mestre suposto, não há tentativa de decifração da mulher amada pelas lentes do ciúme e/ou do proprietário, trata-se de "um amor imenso e cansativo, que deve dizer bem alto: eu quero você mesmo assim.” (RAMOS, 1999, p.13). Submetida ao inexplicável, a voz do diário de Nuno Ramos tenta flagrar as formas sempre submetidas à metamorfose e à dissolução. Sem as justificativas em vão de Bentinho e de Paulo Honório, a voz registra as emendas, os riscos, as deformações, as manchas, as feridas, em seu corpo-diário.

Publicado inicialmente em 2000 em uma tiragem do Autor de 105 exemplares,Minha fantasma foi republicado em 2007 em Ensaio geral: roteiros, ensaios memórias. Nele, a mulher não tem nome, talvez porque não haja "signo para a doença e que o corpo, o corpo profundo, continua inexplorado e mudo." (RAMOS, 2007 p.26), mas, segundo aquele que escreve, "quer ser lembrada. Eu lembro. Eu vou me lembrar." A mulher amada doente, em quadro sério de depressão, é figurada das mais diferentes formas; retomá-las aqui é dizer, também a partir do ensaio de Vilma Arêas que, "se a enfermidade torna inalcançáveis os seres", é ela que engendra as mais diversas "metamorfoses", de quem escreve e da amada, "esculturas que duram um só instante". Espumas. E a carta é endereçada ao mar, destinada à dissolução. O "relato-diário-carta-poema" divide-se em três partes: "Minha fantasma", "Meu cansaço" e "Meu mar". Na primeira, predominam as metamorfoses da mulher amada doente. Na segunda, as da voz do diário. Na terceira, escreve-se a (promessa de) dissolução e indistinção no mar. Uma escrita sem apropriação.

"Tiraram algumas nesgas do alto das pernas dela, um lanho ou um tufo de pêlos. Magra, ela ainda está quente, como um corpo vivo." (RAMOS, 98-99, p. 11) Eis as primeiras linhas de "Minha fantasma”. É espantoso o que nelas se condensa, o que já aponta para a sua batida final que é a da poesia. (ARÊAS, 2011). Nesgas e lanho fundam um campo semântico, que fica bem próximo às metáforas da memória e do trauma: retalho, pedaço, fenda, golpe, ferimento feito com objeto cortante e, ainda, carne cortada em tiras.

Na primeira parte, era "ela" que se metamorfoseava através das comparações elencadas acima, agora, na segunda parte intitulada "Meu cansaço", é o "eu" que deste modo se metamorfoseia: "[...], e sinto que acordo mais deprimido, como quem pisou sem transpor a porta da cadeia (dia, cadeia) e voltou para a cela.”(RAMOS, 1999,p.40) E após essas metamorfoses, a voz do diário delineia uma identidade: "Não há palavras, nem imagens, nem cansaço, mas uma realidade aflita onde tudo sou eu, metamorfose monótona de um único animal espalhado em tudo, por tudo, em todos, por todos."(RAMOS, 1999, p. 42) Tal identidade, contudo, nada tem a ver com um conjunto de atributos, predicativos que contornariam e fixariam o eu. Em última instância, ela tem a ver com a dissolução, indistinção cuja perda de limites ganha forma em "Meu mar". É preciso dizer que as metamorfoses acontecem no plano das figurações, enquanto a realidade, diz quem escreve, permanece estagnada como o mar morto. Desse modo, o corpo cadavérico da mulher doente, que recusa a comida, o amor, a vida cotidiana, esse fantasma melancólico, funda também um tempo melancólico. Um presente que não passa, tempo traumático, e faz com que esse escrito da memória não seja um livro de memórias passadas, mas um diário em que se confundem as lembranças e um futuro incerto demais pautado apenas por perguntas: se você 
morresse? Se você melhorasse? Por quê? Como vai ser? "Não há nada fora da sua melancolia", escreve o marido como "sintoma da doença dela", o que faz com que a forma do diário, escrita no presente e na perplexidade de quem tem a vida suspensa, seja a própria perda que não se consuma.

Em Ensaio geral, Nuno Ramos aloca "Minha fantasma” na parte intitulada "De giro em giro (A parte maldita)", que remete primeiro a um verso do "Inferno" de Dante e entre parênteses a um livro de Bataille. Tanto em Dante quanto em Bataille, a repetição é o eixo. No primeiro, como castigo eterno, giro no suplício; no segundo, a repetição de uma perda sem ganho: puro "dispêndio improdutivo"(BATAILLE, 2013, p.20). Esse escoamento sem fim - afinal "o complexo melancólico se comporta como uma ferida aberta, atraindo para si, de toda parte, energias de investimento" (FREUD, 2011, p.71) - pode talvez ser lido tanto no mar que tudo traga e indistingue, quanto nas fotografias de Eduardo Ortega que acompanham o diário. Foram fotografados cômodos ora completamente vazios, ora com um homem nu deitado no chão paralisado. Assim, a forma melancólica residiria na indistinção entre o objeto e o eu, entre coisa e palavra, entre vazio de significação e paralisia. A perda não tem nome próprio, mas se inscreve em minha fantasma, aqui, o diário é uma escrita que dissolve.E, mesmo na dissolução, insiste uma possibilidade de cicatriz e de esquecimento submetidos a uma carta a escrever, a um desejo de escrita.

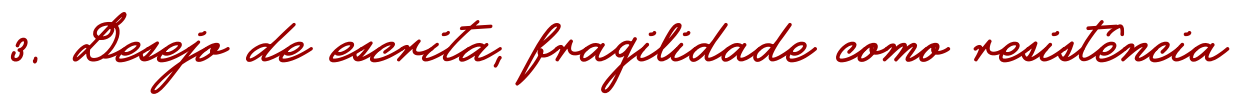

Desejo de escrita, de Vera Lins, publicado em 2013, é composto em forma de diário e, de saída, problematiza a questão do corte, portanto da composição, uma vez que sua forma condensa aproximadamente quarenta anos de escrita. O diário é dividido em setenta e nove seções curtas que recebem títulos variados como "1996 - Emma", "Em cima da cômoda", "2000 - a década" e outros mais de acordo com a convenção de escrita do diário como: “3 de setembro de 2004” em que se anota: "Roubaram minha bolsa. Estou sem documento, mas viva." As três linhas que relatam o assalto e seu transtorno são sucedidas por uma mudança radical de perspectiva, quando se lê:

Despejou tudo na mão da namorada: um batom, um pente, documentos, carteiras, cem reais. Mas ela nem ligou, sabia de seus roubos. Tudo esparramado, mostrando os traços de uma mulher. Olhava indiferentemente, quando deu com duas fotos de um bebê. Se enterneceu. Era isso que queria dele - um filho. (LINS 2013, p. 27)

Quem escreve se coloca aqui em uma cena em que está ausente, perturbando o caráter confessional e a ilusão referencial. Suprime-se a relação entre a cena acontecida e a cena imaginada, a elipse é justamente de algo que poderia remeter à ordem da interioridade como "depois do assalto fiquei imaginando..." O efeito dessa supressão é uma perturbação da perspectiva ao cortar a autorreferência, e, sobretudo, pela perturbação do foco sem nenhuma explicação, o que mostra o valor ficcional desses escritos autobiográficos. Configura-se um microconto no qual o evento pessoal transforma-se em outra cena em que se descortinam outros desejos veiculados por uma quase insignificância: a fotografia roubada de um bebê. O efeito do assalto não é subjetivo, nem provoca nenhuma reflexão sobre a violência urbana, mas, surpreendentemente, coloca em jogo um suposto desejo da namorada do assaltante. Tal deslocamento em direção ao outro, contudo, não deixa de ressoar o fato de se estar "sem documento, mas viva." Procedimento que remete a uma possível linhagem para os escritos de 
Vera Lins, afinal, antes deles, lê-se no diário de Louise Bourgeois: "The only access we have to our volcanic unconscious and to the profound motives of our actions and reactions is through shocks of our encounters with specific people.” (Apud: Gompertz, Will, 2008.)

Essa escrita elíptica, sem pontos de ancoragem tradicionais, não se dá somente em eventos cotidianos, mas principalmente nos eventos em que se esperaria uma elaboração mais digressiva e menos lacunar: a morte do pai e a morte do marido. "Rio, 1969. Papai morreu."(LINS,2013, p. 22)E nenhum traço de romance familiar. Sem enredo, o romance familiar como fundamento do romance burguês é suprimido e fragmentado em frases dos filhos que sobreviveram pelo desconcerto causado. Também sem enredo definido, as histórias amorosas são vividas em cenas nas quais quem escreve está sob o efeito do outro, do homem, com seu corpo e sua vida. Nelas, nessas cenas, o que mais importa é dar uma forma para esse ela diante de um ele sem nenhum contorno sentimental e psicológico.

O fragmento intitulado "Pela paixão" tem início com uma epígrafe de Baudelaire. Esta epígrafe celebra a imortalidade da forma e o fragmento gira em torno do que sobrou de uma história de amor e este resto ganha a seguinte formulação: "nossa potência de vida se inscreveu nos meus filhos, na minha escrita.” (LINS2013, p. 57) Tal escrita não deixa de ser também um inventário de perdas: um ateliê incendiado e um salto mortal em que o homem cai de cabeça.Salto que provoca na mulher um rodopio no armas, em “equilíbrio instável”, ela volta a ficar de pé. Pode-se, então, recolher desse fragmento que, depois queda, da perda no informe, se escreve como quem "pisa em casca de ovo", em um "equilíbrio instável" do que ficou no corpo e nos quadros, "ferindo a folha branca." (LINS, 2013, p.53)

Entre a espuma e o desejo de escrita, os diários de Nuno Ramos, em suas dissoluções, e de Vera Lins, em suas inscrições, entrelaçam a autobiografia à verdade estética. É justamente o compromisso desses diários com uma ética da composição que vem relançar a questão que Proust já colocara sobre a preponderância de uma "verdade estética" sobre qualquer realismo documental: a escrita do diário se alia a sofisticadas exigências formais, uma ética do bem dizer, contra a alienação da mercadoria e do imediato, que acaba por erigir o eu como propriedade e monumento. Neste ponto pode-se concordar e discordar de Blanchot, pois o diário é a âncora que raspa o fundo do cotidiano e, sem se agarrar à vaidade, sabe-fazer com sua nulidade. (BLANCHOT, 2005, p. 273)

\section{Um fora tão cortante"}

Pode-se dizer que as obras aqui analisadas sabem fazer com a nulidade da não-obra, ou seja, os textos literários são profundamente afetados pelo seu fora: a autobiografia e o diário. Em Demorar - Maurice Blanchot, Jacques Derrida lê O instante de minha morte e, situando-o entre a ficção e o testemunho, afirma que o texto de Blanchot perfaz as trajetórias passionais da literatura, fazendo tremer todos os pertencimentos. Tal tremor entre as linhas que separariam vida e morte, eu e ele, ficção e testemunho deve-se à paixão da literatura, de que destaco um de seus sete selos, o último:

Enfim e, sobretudo, "Paixão" conota o padecimento de um limite indeterminável ou indecidível, lá onde qualquer coisa, qualquer $\mathrm{X}$, por exemplo, a literatura, deve tudo sofrer ou suportar, padecer de tudo precisamente porque ela não é ela mesma, não tem essência, mas somente 
funções. Eis a hipótese que gostaria de pôr à prova e submeter à discussão com vocês. Não há essência nem substância da literatura: a literatura não é, não existe, não se mantém em definitivo na identidade de uma natureza ou mesmo de um ser histórico idêntico a ele mesmo. Ela não se mantém na morada, se "morada" designa ao menos a estabilidade essencial de um lugar; [...] A historicidade de sua experiência, pois ela tem uma, não poderia ser essencializada por nenhuma ontologia. Nenhum enunciado, nenhuma forma discursiva é intrinsicamente ou essencialmente literária antes e fora de sua função que lhe assegura ou reconhece um direito, quer dizer, uma intencionalidade específica inscrita num corpo social. $\mathrm{O}$ mesmo enunciado pode ser aqui considerado literário, em uma situação ou de acordo com as convenções dadas, e lá não literário. É o sinal de que a literariedade não é uma propriedade intrínseca de tal ou tal acontecimento discursivo. Mesmo lá onde ela parece demorar, à literatura resta uma função instável e depende de um estatuto jurídico precário. Sua paixão consiste em receber sua determinação de outra coisa que não dela mesma. (DERRIDA [1998], 2015, p.37)

Isso posto, pode-se dizer que é essa condição da literatura - sem essência, sem autodeterminação - o que permite que uma escrita inscreva em um equilíbrio instável e precário o positivo e o negativo, vida e morte, ficção e testemunho, eu e ele, obra e não-obra, verdade estética e autobiografia.

Caberia, então, perguntar sobre o que transmite um escrito que suporta um traço autobiográfico como escrita da exceção, do fora da norma, e se haveria uma lei a qual se submeteria essa escrita da exceção. Se há uma lei para o autobiográfico, essa seria a do corte (que sempre deixa restos inassimiláveis para a representação), que permite falar não de uma essência da autobiografia, mas de um traço, de um valor e de uma função do autobiográfico. Lei, portanto, que produziria um traço de pura diferença. O livro intitulado Jacques Derrida por Geoffrey Bennington e Jacques Derrida, [1991] 1996, começa com uma nota dizendo que ele supõe um contrato: a Geoffrey Bennington caberia uma sistematização do pensamento de Jacques Derrida em sua totalidade; a Jacques Derrida caberia inscrever "a necessidade inelutável do fracasso". Geoffrey Bennington escreve seu Derridabase, o corpus da desconstrução, no corpo do texto; Jacques Derrida escreve sua Circonfissão na margem interna, como se fosse uma nota de pé de página. Com essa operação de escrever à margem, em rodapé, Derrida circuncisa o corpus filosófico com o corpo autobiográfico, quebra a integridade do texto filosófico, contrabandeia para a cena filosófica a cena autobiográfica, macula o logos com seu pênis circuncidado, com o corpo morrente de sua mãe, com as metamorfoses de seu nome próprio e com sua idade que se inscreve em 59 parágrafos. Tais perífrases são como bandagens que envolvem as escaras da mãe (fervilhantes de homonímias!) e o pênis ferido do bebê (que terá permanecido fora da lógica da representação). Em Circonfissão, Jacques Derrida não pode contar a circuncisão que ele sofreu com sete dias de nascimento, um enunciado impossível, mas pode contar com ela em sua enunciação.

"Mas eu, quem soueu?" é a pergunta com a qual Derrida encerra o seu texto O animal que logo sou. (DERRIDA, 2002, p.92) Se Yahvé é aquele que diz "sou aquele que sou", o animal autobiográfico talvez fosse aquele que dissesse "sou aquele que sofre". Enunciado que condensa uma posição ativa e passiva: aquela de quem recebe sua determinação de fora: recebe a circuncisão, recebe a marca da linguagem, do Outro. Traço que somente em uma temporalidade 
retroativa, no só-depois, pode ser lido. Não se trata de recuperar uma origem, mas de dar forma a uma separação primeira. Ler sua inscrição é reinscrever o traço: é o próprio Derrida quem diz que sua vida não foi dedicada senão a refazer esse contorno, esse corte, essa perda. Nessa reinscrição, a cena e o lugar de enunciação se dividem em pelo menos dois: entre o bebê ferido, infans - privado da palavra; e o filósofo que em 59 perífrases inscreve a sua circuncisão, o seu luto pela morte da mãe e o seu girar em torno de um pedaço de carne perdido.

$\mathrm{Na}$ perífrase 39 de Circonfissão, Derrida escreve que a morte de sua mãe "Sultana Esther Georgette Safar Derrida viria esculpir a escrita do fora, dar-lhe sua forma e seu ritmo a partir de uma interrupção incalculável, jamais nenhum de meus textos terá dependido em seu dentro mais essencial de um fora tão cortante." (BENNINGTON, G. \& DERRIDA, J. 1996, p.147). Esse fora cortante assombra não somente as margens da filosofia, ao trazer o corpo do filósofo (seu pênis cortado, seu sangue, suas lágrimas) para as margens internas da sistematização de seu pensamento, como também perturba a escrita autobiográfica. Lá onde teria que se guardar as margens bem definidas de um eu, remete-se a um outro, quer seja a mãe, os irmãos mortos, as linhagens literárias e filosóficas - e não menos importante - a língua francesa. Sob esse fora cortante, ainda é possível dizer eu? "Eu" do bebê circuncidado? "Eu” daquele que, aos 59 anos, a mãe não pode mais reconhecer e nem nomear? Se Maurice Blanchot começou narrativa de $O$ instante de minha morte com "Era um jovem homem" (aquele que já estava na linguagem e tinha até mesmo um manuscrito no quarto alto de uma grande morada), Derrida poderia ter começado sua confissão com "Era um bebê". No entanto, ele começa com outra cena de sangue - ele menino em um laboratório de Argel: encontrar a veia do filho sobrepõe-se a encontrar a veia da mãe. São necessários dois para dar testemunho da experiência do inconsciente- já que o eu não é mais senhor de sua própria casa e é falado por uma língua desde sempre estrangeira.

Ler Circonfissão é ler a autobiografia como fusão, fissura, penetração, interpenetração, fricção e ficção entre as Confissões de Santo Agostinho (2015) e a circuncisão de Jacques Derrida, "um livro aberto no outro". Fusão e fissura entre o santo como aquele que está desde sempre separado e o judeu que, ao perder uma libra de carne, o seu prepúcio, recebe uma marca que, doravante, será aliança com um outro incompreensível. Deus e a mãe, lugares de endereçamento, de envio, em uma assimetria radical. A mãe inscreve a circuncisão no corpo do filho, e jamais lerá uma linha de seu corpus filosófico. Confessar a Geoffrey Bennington, mas ali justamente onde a mãe não escuta. "Como suas mãos são finas, minha sobrevivente, e, mesmo assim, elas me separaram de você e me circuncidaram"(BENNINGTON, G. \& DERRIDA, J. 1996, p.156), diria o filho em lágrimas, em sangue, em prece. As duas palavras circuncisão e confissão, em um gesto desconstrutor, aparecem e desaparecem em uma palavra só. Como as palavras-valise de Joyce. Derrida soletra: circonfissão, mais de uma palavra, mais de uma língua, mais de uma lei, Derrida e Santo Agostinho. Judeu-franco-magrebino. Circonfissão é uma impressão deixada por J.D. a partir da impressão deixada nele. Se a autobiografia se tornou impossível, é preciso escrever - fundir e fissurar: Autobioheterotanatografia. E cortar, decompor e recompor, soletrar: eu, o outro. A vida. A morte. A escrita. A mãe. O nascimento. A morte. A circuncisão.

A pergunta inaugural sobre de quem é a veia desdobra-se em outras sobre a vontade de se matar e as lágrimas - quem quer se matar? Quem chora? Esta última pergunta nos envia a uma outra cena - àquela que se delineia em sua obra póstuma $O$ animal que logo sou(um testamento?), quando Derrida empurra-nos a um deslocamento que não seria qualquer: uma passagem da pergunta "pode o animal falar?"(que mobiliza toda uma linhagem de Aristóteles a Lacan) para uma outra "pode o animal sofrer?". 
Assim, colocar em contiguidade o fora cortante, de Circonfissão, e o sofrer do animal autobiográfico (entre os citados: Proust, Woolf, Duras) implica descentrar o autobiográfico através de um texto afetado pela dor de um fora tão cortante. Não é um descentramento qualquer e não são poucos os efeitos do fora e do sofrimento sobre a escrita autobiográfica e, assim, ela, a autobiografia, também sofre das "paixões da literatura" (entre aquelas indicadas em Demorar, a de não ter essência e de receber sua determinação de fora). Sem que, doravante, o sofrer ocupe o lugar, vazio e espectral, de soberania do eu, da fala, do falo e do significado. A lógica da representação está ferida.

Lemos em $O$ amante que a história da vida daquela que escreve não existe. Sim, não existe o relato concatenado pela lógica causal tradicional, em tempo cronológico, contínuo, que asseguraria a soberania da consciência, do significado e do referente como propriedade. Nuno Ramos e Vera Lins parecem saber disso. A inscrição do traço autobiográfico aparece nas escritas abordadas aqui sem a pretensão de uma reconstituição documental; ao contrário, vigora uma "verdade estética" e, assim, o desejo de escrita é também desejo de inscrever a dor e a ferida da e na própria lógica representativa. Qual lógica representativa? A que trabalha como se o referente estivesse lá, estável, idêntico a si mesmo, apaziguado. Como se apaziguar o encontro com o amante, a doença da mulher amada, o suicídio, a morte da mãe? Não se apazigua: isso que se passa fora do eu perturba a representação, a literatura é assombrada pelo seu fora, e o autobiográfico é forçado pela dor a buscar a forma literária.O romance de Marguerite Duras é atravessado por traços autobiográficos, os diários de Nuno Ramos e Vera Lins são atravessados pela espuma da poesia, e, em suas inscrições, entrelaçam de maneira tensa a literatura e a autobiografia. Afinal, lá onde a destruição impera- no próprio rosto, nos corpos doentes da mulher amada ou da mãe que morre, a forma deverá advir. Só se fere a folha branca quando se sabe que se pisa em casca de ovo.

\section{Referências bibliagráficas}

AGOSTINHO, Santo, Bispo de Hipona. Confissões. Tradução: J. Oliveira Santos e A. Ambrósio de Pina. Petrópolis, Vozes, 2015.

ANDRADE, Paulo Fonseca de. "Só os loucos escrevem completamente". Letras e Letras. Uberlândia 26, 2010.

AREAAS, Vilma. Metamorfoses (Observações sobre O pão do corvo de Nuno Ramos). Disponível em: <http://nunoramos.com.br/portu/depo2.asp?flg_Lingua=1\&cod_Depoimento=29>. 2011. Acesso em: 10/10/2014.

ARFUCH, Leonor. O espaço biográfico: dilemas da subjetividade contemporânea. Tradução: Paloma Vidal. Rio de Janeiro, EDUERJ, 2010.

ARMEL, Aliette. Marguerite Duras et l'autobiographie. Paris, Le Castor Astral, 1990.

BARTHES, Roland. A câmara clara. Tradução: Julio Castañon Guimarães. Rio de Janeiro, Nova Fronteira, 2000.

BATAILLE, George. A parte maldita, precedida de "A noção de dispêndio". 2 ed.rev. Tradução: Júlio Castañon Guimarães. Belo Horizonte, Autêntica Editora, 2013.

BENNINGTON, G. Jacques Derrida por Geoffrey Bennington e Jacques Derrida. Tradução: Anamaria Skinner; revisão técnica: Márcio Gonçalves. Rio de Janeiro, Zahar, 1996. 
BLANCHOT, Maurice. "O diário íntimo e a narrativa”. In: O livro por vir. Tradução: Leyla Perrone-Moisés. São Paulo, Martins Fontes, 2005.

DERRIDA, Jacques.Demorar: Maurice Blanchot. Tradução: Flavia Trocoli e Carla Rodrigues. Florianópolis: Editora UFSC, 2015.

. O animal que logo sou (A seguir). Tradução: Fabio Landa. Editora da UNESP, 2002.

DURAS, Marguerite. (1984). O amante. Tradução: Aulyde Soares Rodrigues. Rio de Janeiro: O Globo. São Paulo, Folha de S. Paulo, 2003.

(1950). Barragem contra o Pacífico. Tradução: Eloisa Araújo Ribeiro. São Paulo, Arx, 2003. . (1985) A dor. Tradução: Vera Adami. Rio de Janeiro, Nova Fronteira, 1986.

FOUCAULT, Michel. Sobre Marguerite Duras. In: Ditos es Escritos III. Organização e seleção de textos: Manoel Barros da Motta. Tradução: Inês Autran Dourado Barbosa. 2 ed. Rio de Janeiro, Forense Universitária, 2006.

FREUD, Sigmund. Luto e melancolia. Tradução, introdução e notas: Marilene Carone. São Paulo, Cosac Naify, 2011.

GOMPERTZ, Will. "My life in art: The day Bourgeois moved me in tears. Disponível em: <https://www.theguardian.com/artanddesign/2008/oct/07/louise.bourgeois >. 2008. Acesso em: $15 / 07 / 2017$.

JOUVENOT, Christian. Marguerite et sa folie: Marguerite Duras et samère. Paris,Harmattan, 2008.

KLINGER, Diana. Escritas de si, escritas do outro: o retorno do autor e a virada etnográfica. 2a Ed. Rio de Janeiro, 7 Letras, 2012.

LAFETÁ, João Luiz. O mundo à revelia. In: A dimensão da noite. Organização: Antonio Arnoni Prado. São Paulo, Duas Cidades/Editora 34, 2004.

LINS, Vera. Desejo de escrita. Rio de Janeiro, Sete Letras, 2013.

MORETTI, Franco. O burguês: entre a literatura e história. Tradução: Alexandre Morales. São Paulo, Três Estrelas, 2014.

POMMIER, Gérard. A exceção feminina, os impasses do gozo. 2a ed. Tradução Dulce Duque Estrada, Rio de Janeiro, Zahar, 1991.

PROUST, Marcel. O tempo redescoberto. Tradução: Lúcia Miguel Pereira. São Paulo, Globo, 2004.

RAMOS, Nuno. Minha Fantasma. São Paulo, 98-99. Edição do Autor. . Ensaio Geral: roteiros, ensaios, memórias. São Paulo, Globo, 2007.

TROCOLI, Flavia. “[...]”. In: Milán-Ramos, J.G. \& Leite, Nina. Terra-Mar: litorais em psicanálise. Campinas: Mercado de Letras, 2010. 